\title{
DỨcin
}

Technological University Dublin ARROW@TU Dublin

2009-09-01

\section{Speed Bumps for Authentic Listening Material}

Marty Meinardi

Technological University Dublin, marty.meinardi@tudublin.ie

Follow this and additional works at: https://arrow.tudublin.ie/aaschlanart

\section{Recommended Citation}

Meinardi, M. (2009), Speed bumps for authentic listening material, ReCALL, vol. 21, part 3, September 2009, Cambridge: Cambridge University Press p. 302-318. DOI:10.1017/S095834400999022X

This Article is brought to you for free and open access by the Languages at ARROW@TU Dublin. It has been accepted for inclusion in Articles by an authorized administrator of ARROW@TU Dublin. For more information, please contact arrow.admin@tudublin.ie, aisling.coyne@tudublin.ie,gerard.connolly@tudublin.ie.

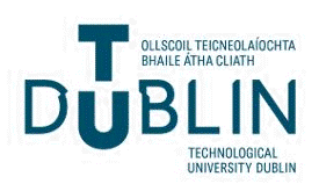




\title{
Speed bumps for authentic listening material
}

Dr Marty Meinardi, Dublin Institute of Technology, School of Languages, Kevin Street, Dublin 8, Ireland. marty.meinardi@dit.ie

\begin{abstract}
:
This article investigates whether authentic NS to NS speech can be made available to the learner listener through the use of a novel slow-down tool. Results from various preliminary tests which have been carried out seem to indicate that the use of a slowdown algorithm in many cases, and in particular in samples with a higher speed rate and word count, leads to an improvement in subjects' ability to perceive and understand what was being uttered in the samples. Tests revealed that even NS listeners (as opposed to NN listeners) prefer to hear authentic NS speech which is either unscripted or is influenced by regional accent, at a slowed down speed. It also seems that 'unexpected' words (such as words with high contextual value, but which cannot be processed in a top-down fashion because of the size of the sound snippet) are initially not understood at the original speed of delivery, even in a scripted and carefully pronounced pedagogic sample. Samples containing chunks or formulaic sequences, however, appear to be easily understood at $100 \%$ by the majority of NS listeners due to the holistic processing of these language units.
\end{abstract}

Word count 189

Keywords: authentic NS to NS speech, slow-down, chunks, formulaic language 
